\title{
Allocation Priority Determination System for Provincial Bridge Maintenance Fund in Special Region of Yogyakarta By Examining Physical Conditions, Operational Cost and Volume of Traffic
}

\author{
Rifqi Aulia Abdillah, Sholihin As'ad, Senot Sangadji \\ Magister Study Program of Infrastructure Maintenance and Rehabilitation, Universitas Sebelas \\ Maret, Jl. Ir. Sutami 36A Kentingan Jebres Surakarta 57126, INDONESIA \\ E-mail: rifqi.aulia18@gmail.com
}

\begin{abstract}
The maintenance of bridges is relatively expensive. Those may lead the maintenance program into a classical problem which is limited of the fund. Therefore, the priority level of bridges maintenance is needed in order to attain an effective and efficient fund usage toward prevalent condition of every bridges in Special Region of Yogyakarta. The objective of this research was to provide the maintenance fund for provincial bridges in Special Region of Yogyakarta. The research covered 10 bridges in Special Region of Yogyakarta. The Assessments method for bridge physical condition was based on guide of Bridge Management System (BMS). As the bridge physical condition was known, the maintenance measure and its needed maintenance cost can be determined. The allocation of fund for each bridge was calculated based on Dynamic Programming Method. The result can be draw that by 5 million rupiah the maintenance fund for each of those 10 bridge of Yogyakarta Special Region is 5 million rupiah for Demak Ijo Bridge, 13 million rupiah for Bedingin Bridge, 10 million rupiah for Denggung Bridge, 5 million rupiah for Ngentak Bridge, 5 million rupiah for Karang Semut Bridge, 8 million rupiah for 2 rd Kronggahan Bridge, 7 million rupiah for Besi Bridge, 8 million rupiah for Cebongan Bridge, 2 million rupiah for Kembang Songo Bridge, 2 million rupiah for 1st Kronggahan Bridge. Those allocation system provide $78,7 \%$ an average percentage on provincial bridges in Special Region of Yogyakarta.
\end{abstract}

Keyword : Fund Allocation System, Provincial Bridge, Special Region of Yogyakarta.

\section{Introduction}

Bridges are one of the most important means of transportation for human beings. The availability of a good transportation system will improve the economy of the community. By with the development of culture and technology, improvement of transportation system should also be done. Because the bridge is an important transport system, connecting traffic that is cut off from obstructions such as rivers, lakes, highways, etc., the collapse or damage of the bridge is disadvantage because it will withstand traffic, and disruption of economic relations. 
Because of Special Region of Yogyakarta which has a lot of river flow and irrigation flow, the existence of the bridge is important in the transportation system in Yogyakarta. The collapse or damage of the bridge in Yogyakarta let alone the bridge connecting the city of Yogyakarta with other cities will cause losses, because it will hinder the traffic around the bridge and affect the economy in Yogyakarta.

The bridge improvement needs a lot of funds, especially in Yogyakarta which has a lot of bridge, therefore need funds to do maintenance or repair on the entire bridge. It is necessary to prioritize the bridge improvement based on the condition of the bridge, so that the use of funds will be used on target and get aphysical condition equitable on every bridge in Special Region of Yogyakarta.

\subsection{Bridge Management System (BMS)}

Bridge Management System (BMS) through the Maintenance and Rehabilitation Guidelines is one way that can be used to ensure that bridges are safe and feasible by investigating the condition of the bridge.

Table 1. Element condition assessment system (BMS 1993)

\begin{tabular}{ccc}
\hline Value & Criteria & Condition of Value \\
\hline Structure (S) & Dangerous & 1 \\
& Not Dangerous & 0 \\
Damaged (R) & Severed & 1 \\
& Not Severed & 0 \\
Quantity (K) & More than 50\% & 1 \\
& Less than 50\% & 0 \\
Function (F) & Not Working Element & 1 \\
& Still Working Element & 0 \\
Influence (P) & Affects Other Elements & 1 \\
& Does not Affect Other Elements & 0 \\
VALUE OF CONDITION & NK=(S+R+K+F+P) & $0 \mathrm{~s} / \mathrm{d} 5$ \\
\hline
\end{tabular}

\subsection{Budget plan}

In the estimation of maintenance costs may refer to the analysis of unit price field of public works. This analysis is the calculation of the need for labor costs, materials and equipment to get a unit price or one job type. 


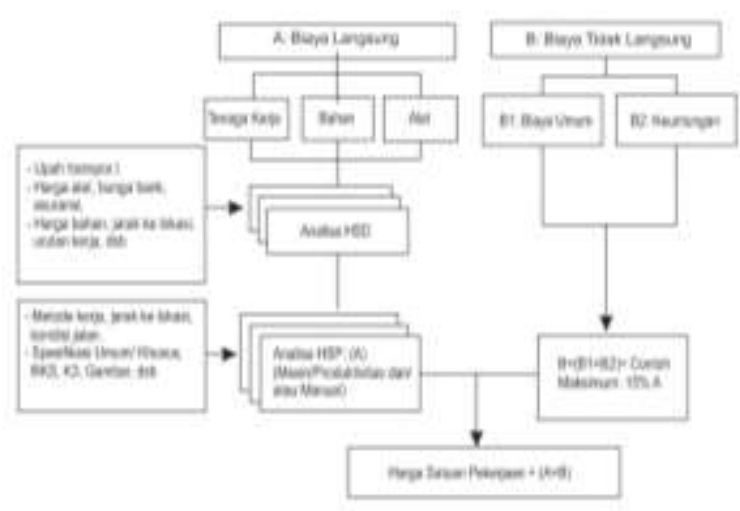

Figure 1. Structure of Unit Price Analysis

\subsection{Bridge Traffic Volume}

The traffic volume shows how many vehicles crossed the bridge in units of time. High traffic volume requires a larger bridge width so that the rider will feel comfortable and safe in crossing the bridge.

In determining the priority order based on traffic can pay attention to the traffic class on the bridge. Classes of traffic are group by LHR ( Average Daily Traffic) on the bridge.

Table 2. The traffic class

\begin{tabular}{cc}
\hline TRAFFIC CLASS & LHR \\
\hline 0 & $<20$ \\
1 & $20-50$ \\
2 & $50-200$ \\
3 & $200-500$ \\
4 & $500-2.000$ \\
5 & $2.000-5.000$ \\
6 & -20.000 \\
7 & $20.000-50.000$ \\
8 & $>50.000$ \\
\hline
\end{tabular}

\subsection{Dynamic Programming}

Mohammad Risal R. (2013) explains that Dynamic Programming is a mathematical technique used to take a decision from a series of interconnected decisions. Dynamic programming provides a systematic procedure for determining optimal combinations. The concept of Dynamic Programming is different from linear programming, there is no standard mathematical form for problem formulation, but in this program a general approach to problem-solving and certain equations used should be according to the problem situation encountered. 


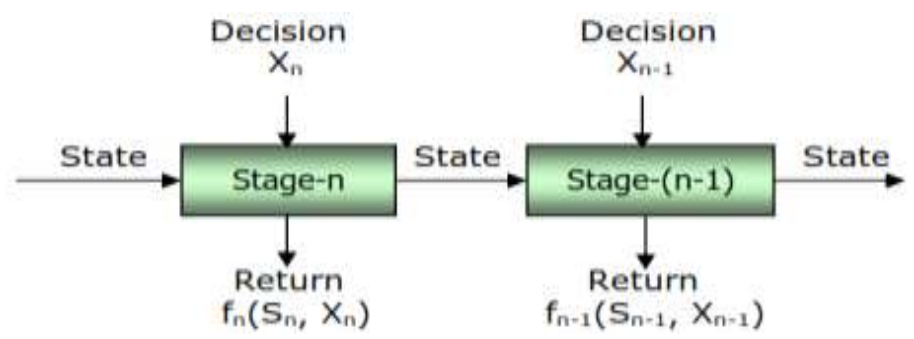

Figure 1. Function on Dynamic Programming

\section{Research Methods}

The location of research that is a bridge located on the provincial road in Special Region of Yogyakarta. The research object consist of 10 bridges, that is Kronggahan Bridge 1, Kronggahan Bridge 2, Denggung Bridge, Ngentak Bridge, Besi Bridge, Demakljo Bridge, Karangsemut Bridge, KembangSongo Bridge, Cebongan Bridge, and Bedingin Bridge. While other bridges are locate in the provincial road segment is secondary data obtained from the Directorat General of Highway Construction and Maintenance Special Region of Yogyakarta.

This type of research is an evaluation research, which in this study do the description and assess a condition of the bridge then carried out the development by providing action solutions and improvement priorities. The research procedure done to solve the problem in this is as follows:

14) Implementation of Data Collection

Data collection is inventory data, image data, BMS data, traffic volume data and cost data available for bridge maintenance under study. Data were obtained from the Directorat General of Highway Construction and Maintenance Special Region of Yogyakarta and field survey.

15) Evaluate

a. Damage Evaluation (using BMS)

b. Evaluation of Improvement

c. Cost Evaluation

d. Evaluation of Bridge Traffic Volume

16) Conducting Analysis

In this research the analys uses Dynamic Programming method to solve the priority problem of bridge handling fund allocation which is expected to produce the right allocation fund decision to get maximum bridge condition.

\section{Results and Discussion}

\subsection{Bridge Condition}

The results of the survey conducted in 10 bridges on the provincial road in Special Region of Yogyakarta can be see in table 3. 
Table 3. Bridge Condition Data

\begin{tabular}{ccccc}
\hline Number of Bridge & Name of Bridge & Cadin & Long $(\mathrm{m})$ & Condition \\
\hline 26.061 .005 .0 & Besi & SLM & 20 & 2 \\
26.062 .003 .0 & Demak Ijo & SLM & 29 & 3 \\
26.068 .002 .0 & Kronggahan 1 & SLM & 6 & 2 \\
26.068 .003 .0 & Kronggahan 2 & SLM & 51 & 3 \\
26.069 .001 .0 & Cebongan & SLM & 5 & 2 \\
26.069 .002 .0 & Bedingin & SLM & 22.5 & 3 \\
26.065 .011 .0 & Ngentak & SLM & 33 & 3 \\
- & Denggung & SLM & 7 & 4 \\
26.002 .003 .0 & Kembang Songo & BTL & 14.8 & 2 \\
26.002 .004 .0 & Karang Semut & BTL & 125.7 & 3 \\
\hline NB: SLM (Sleman), BTL (Bantul) & & &
\end{tabular}

\subsection{Traffic}

The traffic volume can be see from the AADT (Annual Average Daily Traffic) data obtained from the Directorat General of Highway Construction and Maintenance Special Region of Yogyakarta. Based on AADT data can be determined the class of traffic and the feasibility of the bridge in accommodating the volume of traffic.

Table 4. Value Traffic

\begin{tabular}{cccc}
\hline Number & Name of Bridge & AADT & Traffic Class \\
\hline 1 & Besi & 55511 & 8 \\
2 & Demak Ijo & 120994 & 8 \\
3 & Kronggahan 1 & 38903 & 7 \\
4 & Kronggahan 2 & 38903 & 7 \\
5 & Cebongan & 26409 & 7 \\
6 & Bedingin & 26409 & 7 \\
7 & Ngentak & 25586 & 7 \\
8 & Denggung & 25586 & 7 \\
9 & Kembang Songo & 36352 & 7 \\
10 & Karang Semut & 36352 & 7 \\
\hline NB: AADT (Annual Average Daily Traffic)
\end{tabular}

\subsection{Budget plan}

The budget plan is make after the condition and damage of the bridge are known. Budget costs include regular maintenance and repair or reinforcement on damaged bridges. The results of a budget analysis can be see in table 5 .

Table 5. Budget Plan

\begin{tabular}{cccr}
\hline Number & Name of Bridge & \multicolumn{2}{c}{ Budget Plan } \\
\hline 1 & Besi & $\mathrm{Rp}$ & $9,674,375$ \\
2 & Demak Ijo & $\mathrm{Rp}$ & $6,825,093$ \\
3 & Kronggahan 1 & $\mathrm{Rp}$ & $3,468,718$
\end{tabular}




\begin{tabular}{cccr}
\hline Number & Name of Bridge & \multicolumn{2}{c}{ Budget Plan } \\
\hline 4 & Kronggahan 2 & $\mathrm{Rp}$ & $9,203,477$ \\
5 & Cebongan & $\mathrm{Rp}$ & $19,854,460$ \\
6 & Bedingin & $\mathrm{Rp}$ & $30,182,928$ \\
7 & Ngentak & $\mathrm{Rp}$ & $17,022,639$ \\
8 & Denggung & $\mathrm{Rp}$ & $16,358,462$ \\
9 & Kembang Songo & $\mathrm{Rp}$ & $6,749,190$ \\
10 & Karang Semut & $\mathrm{Rp}$ & $11,177,093$ \\
\hline
\end{tabular}

From the table of budget plan we can concluded that total maintenance cost for ten bridges studied is Rp. 130.516.436,-. For example, the budget available for the ten bridges is Rp. 65.000.000,-, it is necessary to do a fund allocation system in order to maintenance fund remain below the existing budget and achieve maximum conditions on every bridge.

\subsection{Bridge Allocation Fund Allocation System}

The fund allocation system was analyzed using the Dynamic Programming method, the analysis taking into account the conditions of bridge, the cost, and the volume of traffic. Stages in the analysis using the Dynamic Programming method as follows:

\section{First simulation:}

17) Convert physical condition into percentage form, to simplify the calculation.

18) Define decision and variables result. The details of the cost budget as an alternative decision (Dn), While the improvement return obtained as a result (Rn).

19) Make decision modeling. Making decision modeling based on priority order on the bridge under study.

20) Analyze each Stage (Bridge). An analysis is done at each stage to determine the decision result at each stage, where the stage decision will affect the next stage decision. The provision in the first simulation analysis, the bridge physical condition value at least reach the condition of $2(67 \%)$.

The result of the first simulation fund allocation system can be see in table 6 .

Table 6. Fund Allocation System

\begin{tabular}{cllcc}
\hline Number & Name of Bridge & & Fund & Condition of Brigde \\
\hline 1 & Bedingin & $\mathrm{Rp}$ & 10.000000 & $67 \%$ \\
2 & Denggung & $\mathrm{Rp}$ & $10,000,000$ & $73 \%$ \\
3 & Ngentak & $\mathrm{Rp}$ & $10,000,000$ & $86 \%$ \\
4 & Demak Ijo & $\mathrm{Rp}$ & $7,000,000$ & $100 \%$ \\
5 & Cebongan & $\mathrm{Rp}$ & $7,000,000$ & $68 \%$ \\
6 & Karang Semut & $\mathrm{Rp}$ & $4,000,000$ & $67 \%$ \\
7 & Kronggahan 2 & $\mathrm{Rp}$ & $4,000,000$ & $70 \%$ \\
8 & Besi & $\mathrm{Rp}$ & $3,000,000$ & $77 \%$
\end{tabular}




\begin{tabular}{clrrr}
9 & Kembang Songo & $\mathrm{Rp}$ & $3,000,000$ & $81 \%$ \\
10 & Kronggahan 1 & $\mathrm{Rp}$ & $4,000,000$ & $100 \%$ \\
\hline & Total & $\mathrm{Rp}$ & $62,000,000$ & $787 \%$ \\
\hline
\end{tabular}

The results of the first simulation, found that the bridge condition is not evenly distributed on each bridge, and the budget available cost is not absorbed all. It is necessary to do a second simulation with the addition of provisions to get a more evenly bridge condition.

\section{The second simulation:}

Step 1-3 is the same as the first simulation. For the fourth step, the provisions in the second simulation analysis are changed with the bridge's physical condition value of at least greater than or equal to $70 \%$ and maximum not more than or equal to $90 \%$. The result of the second simulation fund allocation system analysis can be see in table 7 .

Table 7. Fund Allocation System

\begin{tabular}{cllrc}
\hline Number & Name of Bridge & & \multicolumn{1}{l}{ Fund } & Condition of Brigde \\
\hline 1 & Bedingin & $\mathrm{Rp}$ & 13.000000 & $72 \%$ \\
2 & Denggung & $\mathrm{Rp}$ & $10,000,000$ & $73 \%$ \\
3 & Ngentak & $\mathrm{Rp}$ & $5,000,000$ & $76 \%$ \\
4 & Demak Ijo & $\mathrm{Rp}$ & $5,000,000$ & $86 \%$ \\
5 & Cebongan & $\mathrm{Rp}$ & $8,000,000$ & $70 \%$ \\
6 & Karang Semut & $\mathrm{Rp}$ & $5,000,000$ & $71 \%$ \\
7 & Kronggahan 2 & $\mathrm{Rp}$ & $8,000,000$ & $90 \%$ \\
8 & Besi & $\mathrm{Rp}$ & $7,000,000$ & $90 \%$ \\
9 & Kembang Songo & $\mathrm{Rp}$ & $2,000,000$ & $76 \%$ \\
10 & Kronggahan 1 & $\mathrm{Rp}$ & $2,000,000$ & $83 \%$ \\
\hline
\end{tabular}

The result of the second simulation shows that the bridge condition is more evenly distributed, and available budget has been absorbed.

\section{Conclusion}

Dynamic Programming Analysis resulted in a system of allocation of funds to provincial bridges in the Special Region of Yogyakarta. Funds available for maintenance and repair of 65 million can be allocated as follows: Bedingin Bridge of 12 million, Denggung Bridge of 10 million, Ngentak Bridge of 10 million, Demak Ijo Bridge of 5 million, Cebongan Bridge of 8 million, Karang Semut Bridge of 5 million, Kronggahan Bridge 2 of 5 million, Besi Bridge of 3 million, Kembang Songo Bridge of 5 million, and Kronggahan Bridge 1 of 2 million. The allocation system produces a total bridge percentage of $781 \%$. 


\section{References}

[1] Frangopol DM, Michael PE, and Allen CE 1999 Integration of Maintenance, Repair, and Replacement Decisions in Bridge Management Based on Reliability, Optimization, and Life-Cycle Cost Transportation Research Cilcular 498 India

[2] Hariman F, Christady HH, and Triwiyono A 2007 Evaluasi dan Program Pemeliharaan Jembatan dengan Metode Bridge Management System (BMS) Jurnal Forum Teknik Sipil no XVII/3.

[3] Hidayat T 2016 Sistem Prioritas Penanganan Pemeliharaan Jembatan pada Ruas Jalan Nasional di Provinsi Bengkulu Mempertimbangkan Load Rating Factor TESIS Pascasarjana FT UNS

[4] Nurdin A, Kristiawan SA, and Handayani D 2017 Determination of The Bridge Maintenance and Rehabilitation Priority Scale in Kabupaten Pinrang Jurnal of Physics: Conf series $\mathbf{7 9 5}$

[5] Mohammad Risal R 2017 Program Dinamis (Dynamic Programming) (serial in line) $\quad$ http://mohamadrisalrozakamakali.blogspot.co.id/2013/05/programdinamis-dynamic-programming.html [26 Maret 2017]

[6] Prasetiyowati MI, and Wicaksana A 2013 Implementasi Algoritma Dynamic Programming untuk Multiple Constraints Knapsack Problem Prosiding Seminar Nasional Aplikasi Teknologi Informasi (SNATI):E6-13Yogyakarta

[7] Rashidi M, Gibson P 2011 Proposal of Methodologi for Bridge Condition Assessment Australasian Transport Research Forum 2011 proceedings Adelaide

[8] Rashidi M, Gibson P, and Ho TK 2013 A New Approach to Bridge Infrastructure Managemen Jurnal International Symposium for Next Generation Infrastructure SMART Infrastructure Facility Wollongong

[9] Salma S, Ramanjaneyulu K, and Iyer NR 2012 Condition Rangking and Rating of Bridge Using Fuzzy Logic Fuzzy Logic-Emerging Technologies and Aplications (9):175-202 INTECH Taramani

[10] Sanjay S, Wakchaure, and Kumar N Jha 2012 Review of Inspection Practices, Health Indices, and Condition States for Concrete Bridge, The Indian Concrete Journal

[11] Sinha KC, Labi S, Dkk 2005 Procedures for The Estimation of Pavement and Bridge Preservation Cost for Fiscal Planing TECHNICAL Summary, INDOT Research West Lafayette 